\title{
Legislative Regulation for Hoisting Ownerless Objects Sunk within Seaports
}

\author{
Ksenia V. Golubkina* \\ Admiral Ushakov Maritime State University, Russia
}

\begin{abstract}
Creating a legislative algorithm needed to regulate hoisting of sunken ownerless property is an illustration of existing gaps in national legislation. Legal relations regulated for objects sunk within seaports is touched upon in the Federal Law On Seaports and in the Merchant Shipping Code, but vague wording, lack of an exact algorithm in federal legislation and by-laws creates conditions allowing seaport authorities to stand still and 'shift' responsibility on someone else for resolving an issue of ownerless property. The author proposes a clear regulatory algorithm for recognizing objects sunk within seaports as ownerless, holding responsible for hoisting the said objects and mitigating environmental hazards on economic entities operating in seaports.
\end{abstract}

\section{Introduction}

Regulating relations within state territorial and seaport water areas has always caused a lot of controversy. On the one hand, it is about maritime safety, transport safety, which all affects the sphere of public relations where mandatory regulations are often applied. [1] On the other hand, it is about activities performed by economic entities in seaport water area, about profitmaking, thus being likely about regulatory methods. To date, legal regulation to ensure hoisting of a sunken ownerless object within seaport areas has not been resolved by law. Law enforcement practice varies and raises many questions, namely: a clear algorithm is needed to determine ownership and impose upon owners a duty of maintaining or lifting sunken objects, which hinders efficient uses of transport infrastructure.

It seems reasonable to voice an existing gap in this type of legal regulation, as well as the problem of interdepartmental communications between the bodies regulating the activities of public and private entities in the port water area. [2]

Ownerless objects within seaports impede a safe use of transport infrastructure of seaports, pose a threat to the port ecosystem, however, there is currently no clarity in resolving this issue.

\section{Problem statement}

According to FZ-261 On Seaports, seaport area is understood as "the water area within a seaport, which is under the jurisdiction of the seaport administration and the seaport captain. [3]" Sizable ownerless objects located in the seaport area, which are not properly monitored and maintained can pose a threat to safe navigation and to the ecology of the water area. [10]
The Federal Service for Transport Supervision is a federal body that, according to federal legislation, is responsible for control and oversight in the sphere of transport in the Russian Federation. The transport prosecutor's office is also responsible for supervision in this area, while environmental safety in seaport waters is provided by the environmental prosecutor's office. The system of interdepartmental communications in the authorities of the Russian Federation does not always clearly distinguish between the competences of bodies of various subordination, which can be seen in the example of legal regulation in the seaport water area.

Herein, this issue can be considered as exemplified by federal executive bodies represented by the Ministry of Transport of the Russian Federation, namely the Federal Agency for Sea and River Transport that is in charge of seaport administrations, the Federal Service for Transport Supervision, as well as law enforcement agencies represented by the transport prosecutor's office.

The seaport administration and the seaport captain have administrative powers to ensure safety of navigation in the seaport water area and control safety of hydraulic structures located in the seaport water area.

Despite broad powers of the executive authorities and law enforcement agencies in the field of navigation safety in the seaport water area, the problem of interdepartmental communications can be seen on the example of legal relations regulated for ownerless property in the seaport water area.

Thus, when regulating legal relations in seaport water areas, related to the activities of state bodies and economic entities, one can see the following problems that have not been addressed so far:

- interdepartmental communications of authorities at various levels (federal and regional) and different competences (executive, law enforcement);

\footnotetext{
Corresponding author: golubkina2011@yandex.ru
} 
- gaps in the legal regulation of issues related to hoisting ownerless property in the water area of seaports;

- gaps in the legal regulation of environmental safety in the seaport water area.

\section{Results}

Some problems concerning legal regulation of transport infrastructure hinder the identification of potential uses of port infrastructure. The author analyzed the use of berths and port hydraulic structures that are one of the main facilities constituting the seaport infrastructure. [9]

In the paper, the author considers legal regulation to ensure hoisting of a sunken ownerless object within seaport water areas.

Ownerless objects sunk in seaport water areas pose a serious threat to maritime safety and marine ecosystem.

In the target case, the use of full production capacity of an economic entity is limited by dock No. 1 submerged in the seaport water area.

Reinforced concrete floating dock No. 1 with a lifting capacity of 6,000 tons was built in 1953 in Kherson (dock dimensions: hull length $-130 \mathrm{~m}$, overall width $30.5 \mathrm{~m}$, light draft $-2.5 \mathrm{~m}$, launching draft $-4.3 \mathrm{~m}$, pontoon height along the CLP $-4.5 \mathrm{~m}$ ).

The current state of dock No. 1 resulted from substantial accidental damages back in 1992 caused by natural weather phenomena. Today, the dock is submerged, dilapidated and, due to holes in the bottom and water leakage in the ballast compartments, is mounted on blocks.

The dock poses a real threat to the ecology of the seaport water area and maritime safety.

As part of supervisory functions, the environmental prosecutor's office appealed to the court to recognize an illegal inaction of the seaport administration towards an object located in the seaport water area.

The district court of $\mathrm{N}$. ruled on the case at the suit of the environmental prosecutor's office, in defense of the rights and legitimate interests of an indefinite number of persons, to recognize the omission by the seaport administration as unlawful. By this decision, the district court ruled as illegal the omission by the seaport administration to take measures aimed at clearing the seaport water area from the remains of a sunken floating craft, otherwise referred to as floating dock No. 1, and obliged the seaport administration to remedy the violations detected by informing the authorized public and local self-government bodies on the situation related to floating dock No. 1 sunk in the seaport water area with an aim to establishing ownership of the floating dock.

An economic entity performing activities in seaport water areas is also interested in the execution of this judicial act. Since dock No. 1 is located in close proximity to dock No. 2, the continued presence of dock No. 1 in its current position creates the risk of its further subsidence to the seabed, with the movement of some structures into the pit located under dock No. 2, which can entail significant difficulties in using dock No. 2. Accordingly, these factual circumstances prevent the business entity from production activities and threaten to cause damage to the property owned by the company dock No. 2.

When the dock was damaged and failed to function with the above consequences, it was owned by a state company, and when the company was privatized, the dock was neither listed as privatisable property, nor was it listed as non-privatisable property. In this regard, the lack of information about the dock in any official documentation after 1992 makes it difficult to find and determine ownership so that measures can be taken to recover and dispose of the property.

In August 2013, the business entity received a response from the environmental prosecutor's office, whereby it checked the implementation of the district court's decision and found that the seaport authority had enforced the court decision.

The author believes that an appeal against this letter from the prosecutor's office would not achieve the desired result in view of the following.

The current legislation, in the case of sunken objects, does not impose an obligation on port authorities to hoist up sunken objects, but provides for the publication of information on the timing of hoisting, provide that the owner of the object is not known.

An operative part of the decision held by the district court is worded in such a way as to eliminate the detected violations by informing the authorized state and local authorities about the situation related to the presence of floating dock No. 1 sunk in the seaport water area with a view to identifying ownership of sunken property and lifting the said property. Consequently, as authorized by the above decision, the seaport administration was only obliged to inform the relevant authorities, though it was not obliged to establish the ownership.

Earlier, in January 2013, the interdistrict environmental prosecutor's office reported that as part of the enforcement proceedings, the seaport administration had sent requests for information to the city administration, the Rosprirodnadzor department, the territorial wetlands, the territorial office of the Federal Agency for State Property Management.

In this regard, the issue of appealing against an order terminating enforcement proceedings also seems to have no prospect of success.

One of the options for resolving the situation is to sue the territorial administration of the Federal Agency for State Property Management to remove the obstacles to the use of the wharf by hoisting and disposing of sunken floating dock No. 1.

When it comes to the existing court practice, Resolution of the Plenum of the Supreme Arbitration Court of the Russian Federation No. 10/22 dated April 29, 2010 explains that "a claim to remove violations of rights not related to dispossession shall be satisfied if the plaintiff proves that he/she is the owner or a person in possession of the property on the grounds provided for by law or contract, and that the actions of the defendant, not related to dispossession, violate his/her right of ownership or legal possession. [4]" Therefore, based on this explanation, in the case of ownerless property sunk 
in the water area of a seaport, the court may oblige FASPM to remedy the violation of the plaintiff's right, which is preferable.

Given that dock No. 1 is located in the area of berth No. 12 leased by an economic entity and creates obstacles in the use of this berth, the economic entity is entitled to sue with the aforementioned claims.

During the privatization of the state-owned company engaged in economic activities in the port, dock No. 1 was not included in the list of property to be privatized as of 27.10.1992, nor was it included in the list of property not subject to privatization Thus, dock No. 1 was not transferred to the ownership of the present economic entity.

Based on the provisions of the regulations of the RSFSR that were in effect before the Civil Code of the Russian Federation and the relevant laws of the RSFSR were adopted, the state was the owner of dock No. 1 that was part of the property portfolio owned by the state company. Therefore, dock No. 1 continues to be the federal property, i.e. the property of the Russian Federation. However, according to the norm of the Civil Code of the Russian Federation (Article 236), the waiver of ownership does not entail the termination of the owner's rights and obligations with respect to the relevant property until another person acquires the ownership right to it.

Consequently, the subject matter of the case would be the fact that the Russian Federation was and currently is the owner of the dock and that dock No. 1 sunk near the berth violates the right of the economic entity to freely use the leased berth.

Today, no definite decision has been taken on the situation described.

A similar situation is illustrated in the ruling of the judicial panel for civil cases in a similar case. The transport prosecutor who had brought a claim for the protection of rights and legitimate interests of an indefinite number of persons was denied the satisfaction of the claim on the grounds that the sunken vessel could not be recognized as ownerless property under the general rules.[5] In addition, the court found that there was no objective data in the case to allow the court to conclude that the sunken ship posed a threat to the ecology of the seaport water area, could cause damage to marine flora and fauna, and posed a danger to navigation in the port, as claimed by the transport prosecutor.

Moreover, the problem of unsettled similar legal relations is set forth in a court decision held by a district court in Tomsk Oblast. The court decided that the claims against the administration of the Kirov district for the obligation to organize the hoisting, removal or disposal of four ownerless vessels located within the boundaries of inland waterways, attributed by law to the property of the Russian Federation should be rejected.

Besides, the inaction of the Administration of the $\mathrm{Ob}$ Basin of Inland Waterways not to take measures to hoist and dismantle sunken ships violates the rights of an indefinite circle of persons on maritime safety, while the presence of these ships on inland waterways harms the environment. Therefore, the claims of the Tomsk
Transport Prosecutor against the Administration of the Ob Basin of Inland Waterways are to be satisfied. [6]

A detailed regulation of relations to control hoisting, removal and disposal of property sunk within inland maritime water is laid down in Chapter VII on Sunken Property of the Merchant Shipping Code of the Russian Federation [7].

However, the chapter regulates the procedure for dealing with the property provided that the owner of the property is known. If the owner is unknown or it is not possible to determine ownership, there is a gap in the legal norm regulating ownerless property. Article 111 Chapter VII on Sunken Property of the Merchant Shipping Code of the Russian Federation states that seaport administration has the right to hoist, remove or destroy sunken property, which is dispositive.

Thus, if a sunken property has no ownership, the seaport administration is not obliged to hoist or destroy the said property. It seems expedient to give this norm an imperative character and oblige the seaport administration to lift or destroy ownerless wrecks within internal maritime waters of the state.

With regard to ownerless wrecked property within seaports, the author considers it reasonable to charge the costs of raising, removing or destroying the ownerless wrecked property on the entities engaged in business activities in the said port, as applicable to their actual participation in activities.

\section{Discussion}

Based on the study, despite a significant number of state bodies that are obliged to oversee safety in seaports, there are gaps with regard to ownerless property in the national legislation. It is sometimes difficult to determine a specific entity obliged to hoist this property and eliminate all the consequences caused by the property at its own expense. In this case, it seems possible to draw a conclusion about the problem of interdepartmental communications within federal and regional authorities, when each of the bodies performs certain functions strictly to the letter of the law, but the problem is not being addressed. [2]

There is no doubt that there is a need for a clear algorithm for recognizing objects sunk within seaports as ownerless and for taking further actions to minimize negative implications for maritime safety and the environment.

\section{Conclusion}

The author proposes the following sequence of actions regarding ownerless property.

Firstly, it is necessary to establish in court that an object has no owner, the plaintiff here should be supervisory authorities that could be the transport prosecutor's office, or the environmental prosecutor's office.

Secondly, if a wrecked ownerless property is located within a seaport, seaport administration should be responsible for hoisting ownerless property and cleaning 
the water area, while the costs of hoisting the ownerless property and cleaning the water area should be assigned to business entities engaged in this type of activity in the seaport. If there is more than one such entity, civil liability should be divided between them in a contractual or judicial manner. It is correct to empower seaport administrations, transport and environmental prosecutors to oversee their actions.

Thirdly, if a wrecked ownerless property is located within internal sea waters, but not within water area of a port, the obligation to hoist, remove or destroy the sunken ownerless property should be assigned to the seaport administration by analogy with Article 111 Chapter VII on Sunken Property of the Merchant Shipping Code of the Russian Federation. The author suggests the following wording for this article: Article 111 "The seaport administration is obliged to hoist sunken property and, if necessary, remove or destroy it if: ... the owner of the sunken property is not established". [7]

There is also a need to establish a presumption of environmental hazard [8] of any sunken property and develop public-private partnership projects to clean up inland sea waters, including from sunken objects [9].

\section{References}

1. A.L. Boran-Keshishyan, S.I. Kondratiev, A.N. Tomilin, The development of bank of test tasks for the state final examination of graduates from maritime educational institutions, Marine intellectual technologies, 1(43), 2, 149-156 (2019)

2. S.K. Abrahamyan, K.V. Golubkina, Interdepartamental cooperation as regards water transport in Russian Federation, Marine intellectual technologies, 1(43), 2, 82-85 (2019)
3. Federal Law No. 261-FZ of November 8, 2007 "On Seaports in the Russian Federation and on Amendments to Certain Legislative Acts of the Russian Federation". Retrieved from: SPS ConsultantPlus

4. Resolution of the Plenum of the Supreme Court of the Russian Federation No. 10, the Plenum of the Supreme Court of the Russian Federation No. 22 of 29.04.2010 (ed. of 23.06.2015) "On some issues arising in judicial practice in resolving disputes related to the protection of Property Rights and other property rights". Retrieved from: SPS ConsultantPlus

5. Retrieved from: http://www.gcourts.ru/case/33017443

6. Retrieved from: http://arbitr.garant.ru/\#/document/110423380.

7. "Code of Commercial Navigation of the Russian Federation" of 30.04.1999 N 81-FZ (ed. of 08.06.2020). Retrieved from: SPS ConsultantPlus

8. V.V. Zaslonov, A.A. Golovina, A.N. Popov, Creating a Crewless Ship in the Framework of the Technological Paradigm of the Russian Federation, Lecture Notes in Networks and Systems, 1(115), 468-474 (2020)

9. O.N. Baburina, M.V. Botnaruyk, S.I. Kondratiev, Intellectual problems of implementing road map for development of russian marine industry (MariNet) in the framework of National technological initiative, Marine intellectual technologies, 3(41), 1, 190-198 (2018)

10. V. V. Zaslonov, A. A. Golovina, The essence and problematic aspects of using the "flock" method for managing a group of marine mobile objects, Marine Intellectual Technologies, 2(4) (2021) 